\title{
Energy Utilization Pattern of Pigeon Pea Farmers in Vijayapur District of Karnataka, India
}

\author{
P. Nagarjuna Reddy ${ }^{1^{*}}$ and Jagadeesh G. Angadi ${ }^{2}$ \\ ${ }^{1}$ Department of Agricultural Extension Education, \\ UAS, Dharwad-580005, India \\ *Corresponding author
}

\section{A B S T R A C T}

\section{Keywords \\ Energy use, Pigeon pea, Ploughing, Harrowing and inorganic fertilizers \\ Article Info \\ Accepted: \\ 12 July 2018 \\ Available Online: \\ 10 August 2018}

The study examined the energy use pattern of pigeon pea farmers in Vijayapura district of Karnataka. Data was gathered from a sample of 80 farmers through a structured interview schedule. Energy consumption was high in ploughing operation $\left(1,059.60 \mathrm{MJ} \mathrm{ha}^{-1}\right)$ followed by other harrowing $\left(675.70 \mathrm{MJ}^{-1}\right)$. There was significant difference between small and large farmers in energy consumption through ploughing, harrowing, sowing, harvesting and threshing operations. Energy consumption through inorganic fertilizers was found to be the dominant source in all farm sizes. There was significant difference in energy consumption through human and machinery sources between small and large farmers.

\section{Introduction}

Agriculture is both a producer and consumer of energy. Energy input-output analysis is usually used to evaluate the efficiency and environmental impacts of production systems (Ozkan et al., 2004). Energy use in agriculture has been increasing in response to increasing population, limited supply of arable land, and a desire for higher standards of living (Kizilaslan, 2009). In modern agriculture system input energy is very much higher than in traditional agriculture system, but energy use efficiency has been reduced in response to no affective use of input energy.
Pulses play a major role in providing overall prosperity to the small and marginal farmers through nutritional security by meeting their dietary protein requirements and improving production base through conservation of natural resources. Inclusion of pulses in the cropping system as a crop rotation improves soil fertility and crop productivity of cereals and oil seeds. The main objective of this study is analysis of energy use in pigon pea.

The present study was undertaken in Vijayapura district during the year 2016-17. Keeping the cropping pattern and highest area under pigeon pea in University of 
Agricultural Sciences, Dharwad jurisdiction, Vijayapura district was selected. Two taluks were randomly selected and from each taluk two villages were selected randomly.

From each village 20 farmers were selected comprising 10 large farmers and 10 small farmers using stratified random sampling thus making a sample of 80 .

Personal interview method was followed for data collection using an interview schedule developed for the study. Statistical tools mean and t-test have been used for the study.

\section{Materials and Methods}

\section{Energy utilization}

Energy from inputs and outputs were calculated by converting the physical units of inputs and outputs into respective energy units by using appropriate energy equivalents given by Mittal et al., (1985) and followed by Pradhan et al., (2015).

\section{Energy ratio}

It is the ratio of output energy to input energy. Energy ratio = Energy output $\left(\mathrm{MJ} \mathrm{ha}{ }^{-1}\right) /$ Energy input $\left(\mathrm{MJ} \mathrm{ha}^{-1}\right)$

\section{Contribution of energy utilization to the productivity}

Specific energy ( $\mathrm{MJ} \mathrm{kg}^{-1}$ ) has been widely used in energy analysis to express the quantity of energy utilized to produce unit quantity of the product.

Specific energy $\left(\mathrm{MJ} \mathrm{kg}^{-1}\right)=$

Input energy (MJ)

$$
\text { Crop yield }(\mathrm{kg})
$$

\section{Results and Discussion}

Operation-wise energy input in pigeon pea (MJ ha' ${ }^{-1}$ )

Results of operation-wise energy input in pigeon pea are presented in Table 1. Energy consumption was high in ploughing operation (1,059.60 $\left.\mathrm{MJ} \mathrm{ha}^{-1}\right)$ followed by harrowing (675.70 MJ ha $\left.{ }^{-1}\right)$. Harvesting operation constituted $606.62 \mathrm{MJ} \mathrm{ha}^{-1}$ followed by weeding/intercultivation (599.72 $\mathrm{MJ} \mathrm{ha}^{-\mathbf{1}}$ ) and threshing (573.07 MJ ha $\left.^{-1}\right)$. Energy consumption through sowing was $367.70 \mathrm{MJ}$ $\mathrm{ha}^{-1}$. The results are in conformity with the findings of Guruswamy et al., (2001). The high energy consumed for land preparation was due to use of tractors with matching implements by the farmers.

The t-test revealed significant difference between small and large farmers in energy input through ploughing, harrowing, sowing, harvesting and threshing operations.

\section{Source-wise energy input in pigeon pea (MJ ha' ${ }^{-1}$ )}

This includes the share of direct energy sources like human, bullock and machine labour and indirect sources of energy like seeds, fertilizers, pesticides, etc. The results relating to source-wise energy input in maize are depicted in Table 2.

Inorganic fertilizers consumed highest energy to the extent of 4,637.05 $\mathrm{MJ} \mathrm{ha}^{-1}$ followed by machinery energy $\left(2,632.98 \mathrm{MJ} \mathrm{ha}^{-1}\right)$. Energy consumption through human and bullock was 754.21 MJ $\mathrm{ha}^{-1}$ and 559.55 MJ $\mathrm{ha}^{-1}$ respectively. Energy consumed through seed was 229.68 $\mathrm{MJ} \mathrm{ha}^{-1}$ (Table 2). The results are not in line with the findings of Guruswamy et al., (2001). Application of fertilizers has increased over the period. The energy through machinery has also seen increasing over the 
period with the usage of more tractor drawn implements for performing the operations.

Energy consumed through machinery was 3,189.13 $\mathrm{MJ} \mathrm{ha}^{-1}$ among large farmers. While, it was 2,076.83 $\mathrm{MJ} \mathrm{ha}^{-1}$ among small farmers. There was significant difference in energy consumption through human and machinery sources between small and large farmers.

\section{Output input energy ratio in pigeon pea}

The output input energy ratio in pigeon pea was 2.06 (Table 3 ). The results are not in line with the findings of Guruswamy et al., (2001). Application of inorganic fertilizers and farm yard manure in the form of input energy was found high compared to the recommended dosage and low productivity led to decrease in input output energy ratio.

Table.1 Operation-wise energy input in pigeon pea $\left(\mathrm{MJ} \mathrm{ha}^{-1}\right)$

\begin{tabular}{|c|c|c|c|c|c|c|}
\hline \multirow{2}{*}{$\begin{array}{l}\text { Sl. } \\
\text { No. }\end{array}$} & \multirow{2}{*}{\multicolumn{2}{|c|}{ Operation }} & \multicolumn{3}{|c|}{ Input energy coefficient $\left(\mathrm{MJ} \mathrm{ha}^{-1}\right)$} & \multirow[t]{2}{*}{$\mathrm{t}$} \\
\hline & & & Overall & $\begin{array}{c}\text { Small } \\
\text { farmers }\end{array}$ & $\begin{array}{l}\text { Large } \\
\text { farmers }\end{array}$ & \\
\hline \multirow[t]{3}{*}{1.} & \multirow{3}{*}{$\begin{array}{l}\text { Land } \\
\text { preparation }\end{array}$} & Ploughing & $1,059.60$ & $1,008.93$ & $1,110.27$ & $2.36^{*}$ \\
\hline & & Harrowing & 675.70 & 624.00 & 727.40 & $2.02 *$ \\
\hline & & $\begin{array}{l}\text { Clod } \\
\text { crushing }\end{array}$ & 268.62 & 255.85 & 281.40 & $0.89 \mathrm{NS}$ \\
\hline 2. & \multicolumn{2}{|l|}{ Sowing } & 367.70 & 306.35 & 429.07 & $2.85^{* *}$ \\
\hline 3. & \multicolumn{2}{|c|}{ Weeding/Intercultivation } & 599.72 & 580.35 & 619.10 & $0.64 \mathrm{NS}$ \\
\hline 4. & \multicolumn{2}{|c|}{$\begin{array}{l}\text { Plant protection chemical } \\
\text { application }\end{array}$} & 195.67 & 170.60 & 220.75 & $1.85 \mathrm{NS}$ \\
\hline 5. & \multicolumn{2}{|l|}{ Harvesting } & 606.62 & 551.37 & 661.87 & $2.27 *$ \\
\hline 6. & \multicolumn{2}{|l|}{ Threshing } & 573.07 & 440.55 & 705.60 & $3.56 * *$ \\
\hline
\end{tabular}

* : significant at 0.05 level

**: significant at 0.01 level

NS: Non-significant

Table.2 Source-wise energy input in pigeon pea $\left(\mathrm{MJ} \mathrm{ha}^{-1}\right)$

\begin{tabular}{|c|c|c|c|c|c|}
\hline \multirow{2}{*}{$\begin{array}{l}\text { Sl. } \\
\text { No. }\end{array}$} & \multirow[t]{2}{*}{ Operation } & \multicolumn{3}{|c|}{ Input energy coefficient $\left(\mathrm{MJ} \mathrm{ha}^{-1}\right)$} & \multirow[t]{2}{*}{$\mathrm{t}$} \\
\hline & & Overall & $\begin{array}{c}\text { Small } \\
\text { farmers }\end{array}$ & $\begin{array}{c}\text { Large } \\
\text { farmers }\end{array}$ & \\
\hline 1. & Human & 754.21 & 994.20 & 514.23 & $3.53 * *$ \\
\hline 2. & Bullock & 559.55 & 592.05 & 527.05 & $1.78 \mathrm{NS}$ \\
\hline 3. & Machinery & $2,632.98$ & $2,076.83$ & $3,189.13$ & $3.94 * *$ \\
\hline 4. & Farm yard manure & 820.15 & 801.25 & 839.05 & $0.94 \mathrm{NS}$ \\
\hline 5. & Seed & 229.68 & 238.88 & 220.50 & $1.54 \mathrm{NS}$ \\
\hline 6. & Inorganic fertilizers & $4,637.05$ & $4,601.13$ & $4,672.98$ & $1.12 \mathrm{NS}$ \\
\hline 7. & Plant protection chemicals & 72.18 & 72.75 & 71.63 & $0.73 \mathrm{NS}$ \\
\hline
\end{tabular}

* : significant at 0.05 level

**: significant at 0.01 level

NS: Non-significant 
Table.3 Output input energy ratio in pigeon pea

\begin{tabular}{|c|l|c|c|c|}
\hline Sl. No. & \multicolumn{1}{|c}{ Parameters } & Overall & Small farmers & Large farmers \\
\hline $\mathbf{1 .}$ & Input energy $\left(\mathrm{MJ} \mathrm{ha}^{-\mathbf{1}}\right)$ & $9,705.78$ & $9,377.08$ & $10,034.55$ \\
\hline $\mathbf{2 .}$ & \left.${\text { Output energy }\left(\mathrm{MJ} \mathrm{ha}^{-1}\right)}^{-1}\right)$ & $20,028.75$ & $18,926.25$ & $21,131.25$ \\
\hline 3. & Energy ratio (Output/Input) & 2.06 & 2.01 & 2.10 \\
\hline
\end{tabular}

Table.4 Contribution of energy utilization to the productivity in pigeon pea

\begin{tabular}{|r|l|c|c|c|}
\hline $\begin{array}{r}\text { Sl. } \\
\text { No. }\end{array}$ & \multicolumn{1}{|c|}{ Parameters } & Overall & Small farmers & Large farmers \\
\hline 1. & Input energy $\left(\mathrm{MJ} \mathrm{ha}^{-\mathbf{1}}\right)$ & $9,705.78$ & $9,377.075$ & $10,034.55$ \\
\hline 2. & Yield $\left(\mathrm{Kg} \mathrm{ha}^{-\mathbf{1}}\right)$ & $1,362.50$ & $1,287.50$ & $1,437.50$ \\
\hline 3. & Specific energy $\left(\mathrm{MJ} \mathrm{kg}^{-\mathbf{1}}\right)$ & 7.12 & 7.28 & 6.98 \\
\hline
\end{tabular}

Contribution of energy utilization to the productivity in pigeon pea

Specific energy is calculated to find the contribution of energy utilized to the productivity.

Specific energy in pigeon pea was $7.12 \mathrm{MJ}$ $\mathrm{kg}^{-1}$ (Table 4). Contribution of energy for producing one $\mathrm{kg}$ of seed was $7.12 \mathrm{MJ}$. The results are not in line with the findings of Patil (2014) in which the specific energy was 3.38 $\mathrm{MJ} \mathrm{kg}$. Over dosage of inorganic fertilizers and manures by farmers than recommended and low productivity led to increase in specific energy. Even though large farmers utilized more energy, specific energy of small farmers was found more compared to large farmers. This was reflected in low productivity of crop of small farmers compared to large farmers.

In conclusion, energy consumption for land preparation was high due to use of tractors with matching implements by the farmers.
Energy consumption through inorganic fertilizers as the application of fertilizers has increased over the period. The energy through machinery has also seen increasing over the period with the usage of more tractor drawn implements for performing the operations. Application of inorganic fertilizers and farm yard manure in the form of input energy was found high compared to the recommended dosage and low productivity led to decrease in input output energy ratio.

\section{References}

Guruswamy, T., Desai, S. R. and Veerangouda, M., 2001, Energy requirements for crop production under Dryland agriculture in Karnataka: A case study. Karnataka J. Agric. Sci., 14(1): 101-105.

Kizilaslan H., 2009, Input-output energy analysis of cherries production in Tokat Province of Turkey. Applied Energy 86: 1354-1358.

Mittal, V. K., Mittal, J. P. and Dhawan, K. C., 1985, Research digest on energy 
requirements in agricultural sector. All India coordinated research project on energy requirements in agricultural sector, Punjab Agric. Univ. Ludhiana, p. 259.

Ozkan, B., Akcaoz, H. and Fert, C., 2004, Energy input-output analysis in Turkish agriculture. Renew Energy 29: 39-51.

Patil, S. L., Mishra, P. K., Loganandhan, N., Ramesha, M. N. and Math, S. K. N., 2014, Energy, economics and water use efficiency of chickpea cultivars in vertisols of semi-arid tropics, India, Current Sci., 107(4): 656-664.

Pradhan, P., Naik, R. K., Sahu, M. and Thakur, C., 2015, A study on the energy use pattern and cost of production under transplanted paddy production system in Chhattisgarh, India. Int. J. Eng. Res. Tech., 4(7): 1014-1018.

\section{How to cite this article:}

Nagarjuna Reddy, P. and Jagadeesh G. Angadi. 2018. Energy Utilization Pattern of Pigeon Pea Farmers in Vijayapur District of Karnataka. Int.J.Curr.Microbiol.App.Sci. 7(08): 1839-1843. doi: https://doi.org/10.20546/ijcmas.2018.708.211 